\title{
The State of Art Appreciation among Nine- and Ten- Year-Old Students in Slovenian Primary Schools
}

Jerneja Herzog ${ }^{\star 1}$ AND Matjaž DUH ${ }^{2}$

$\approx$ In the contemporary process of teaching fine arts, the students' own creative expression and art appreciation are used to encourage learners towards both perception and reception; consequently, the evaluation and internalisation of works of art play an equally important role. In art education practice, we manage to provide adequate incentives and are able to follow incentives for artistic expression, but pay less attention to developing art appreciation. This research presents the results of a study that monitored the development of art appreciation abilities among 9- and 10-year-old students (4th and 5 th grades; $\mathrm{n}=2794$ ) in Slovenian primary schools. The level of art appreciation abilities was rather average, but was more developed among older students and girls. In monitoring the school stratum, we did, however, notice a statistically significant difference regarding perception, whereby students in urban schools performed better than their peers in suburban schools.

Keywords: art appreciation, perception, primary school, reception, visual arts education 


\section{Stanje ravni likovne apreciacije med devet- in desetletnimi učenci v slovenskih osnovnih šolah}

Jerneja Herzog in Matjaž Duh

$\propto$ V sodobnem procesu poučevanja likovne umetnosti sta lastno ustvarjalno izražanje učencev in likovna apreciacija namenjena spodbudi likovne percepcije in recepcije učencev; posledično imata vrednotenje in ponotranjenje umetniških del enako pomembno vlogo. V likovnovzgojni praksi uspevamo zagotoviti ustrezne spodbude za likovno izražanje in sledenje, medtem ko manj pozornosti namenjamo razvoju likovne apreciacije. Ta raziskava predstavlja izsledke študije, ki je spremljala razvoj sposobnosti likovne apreciacije med učenci, starimi od 9 do 10 let (4. in 5. razred; $n=2.794$ ) v slovenskih osnovnih šolah. Stopnja sposobnosti likovne apreciacije je bila precej povprečna, se je pa pokazala za razvitejšo pri starejših učencih in deklicah. Pri spremljanju stratuma šol smo opazili statistično pomembno razliko pri percepciji, pri kateri so se učenci v mestnih šolah bolje odrezali kot njihovi vrstniki v primestnih šolah.

Ključne besede: likovna apreciacija, osnovna šola, recepcija, percepcija, poučevanje likovne umetnosti 


\section{Introduction}

Visual arts education has five main positive outcomes: art-sense-making, enriching experience, aesthetic appreciation, entertainment, and bonding. (Lomas, 2016). "Creativity and achievement, in seemingly all age groups, may be related to personal commitment and investment. It may be that time is necessary for the creative process, or that creative people tend to devote themselves to whatever grabs their interest « (Healey \& Runco, 2006, p. 39). In primary school, modern didactics of arts education is based on the development of the productive - hence artistically creative - and receptive artistic abilities of students. The latter also includes art appreciation, whereby students are challenged by perceiving and receiving, and hence by evaluating and internalising works of art. »The development of artistic design, sensitivity for artistic language and the aesthetic experience in the process of expression, obtaining technical experiences, work with different materials and similar have a beneficial effect on the development of art appreciation abilities « (Duh et al., 2012, p. 640). The development of artistic appreciation is based on developing a perception of the artwork that is as subtle as possible. In the process, students are trained to see the work of art, understand it and enjoy it. The factors that influence art appreciation are numerous and are not limited to understanding the artist's intention (Jucker \& Barrett, 2011). Art appreciation focuses on the »intrinsic values of art, by analysing and appreciating the qualities specific to the various artistic elements, such as composition, form, colour, light and space« (Law, 2010, p. 94). At the affective and cognitive levels, artistic appreciation thus deals with emotions and feelings about art, while including knowing and understanding its development. If both objectives - the affective and the cognitive - are met, the result is artistic appreciation (Seabolt, 2001). Tinio (2013) believes that, »The aesthetic experience of art begins with the perception of the surface features of an artwork and peaks when the viewer achieves a sense of having grasped an underlying meaning, context, or concept regarding the work that might have some personal relevance« (Tinio, 2013, p. 265). When we see the context of the theory of aesthetic experience, we can say that, »Sensibility to the appearance of works of art is a precondition for the constitution of concealed emotions, because the work of art provides a distinct form to the emotion in question « (Funch et al., 2012, p. 98). One's own ideas are related to associations, which in artistic education are revealed as a self-assumed way of thinking, primarily because "as a component of creative artistic activity they refer directly to the subject arts and to its receptive, productive, and reflective treatment« (Seumel, 2001, p. 8). Today, we know that art appreciation abilities are just as equally present in students as all of their other abilities. 
The goal of developing artistic appreciation is for students to be able to identify the complex relations that constitute a work of art with reference to a few exemplary works. They thus acquire aesthetic experience that requires sensory, emotional and cognitive competences. The development of this perception is probably the most important phase in the development of (artistic) appreciation. Students can respond to one and the same work of art in three ways: (1) at the emotional level; (2) at the associative level (relating to the associations that arise in the onlooker in the presence of an artwork); (3) at the formal intellectual level (relating to the responses that arise in onlookers after formal analysis and interpretation of an artwork). These three types are subject to oscillation and change, as they depend on both the viewer and the artwork (Duh \& Zupančič, 2013). Roald articulates this issue similarly (2008), distinguishing between three types of experience. (1) The first type of experience with art emerges as a fairly direct and immediate response to what appears as a "good Gestalt«, or a pleasurable response to what is regarded as beautiful. What is beautiful is manifest in a specific shape that is inherently meaningful; the mere experience of the form is pleasing and does not demand any considerations of its underlying significance. It only demands attentiveness and wonder. (2) The second type of experience appears as an intellectual appreciation of art, where the focus is upon understanding. It can comprise an understanding of other cultures, and thereby, indirectly one's own. It can also take the form of learning about new trends, styles and artists. (3) The third type of experience appears as a more bodily type of emotionality. The body is always there, of course, but can be more or less pronounced or thematic in the experience of an emotion. In this kind of experience, the body is at the centre of the experience, and the bodily sensations follow the nature of the exhibit (Roald, 2008, pp. 208-209). In other words, "art appreciation is highly idiosyncratic and seems to be in the eye of the beholder " (Leder et al., 2012). Observing and receiving an artwork, and thus the development of art appreciation, go through multiple phases that various authors interpret in different ways. Pagany (1993) determines four phases: (1) the perception of the artwork with all of the senses; (2) the release of emotions; (3) the transformation of the images into speech according to the impression left by the painting on the student; and (4) activity. A group of authors (Ishizaki et al., 2008) emphasise six fields in art appreciation: (1) Association, (2) Observation, (3) Impression, (4) Analysis, (5) Interpretation and (6) Judgment. Another group of authors (Anderson, 1988; Clark, 1960; Feldman, 1987; and Mahon Jones, 1986; as summarised in Arts Education, 1996) describe seven steps or phases: (1) preparation for viewing; (2) first impression; (3) description; (4) analysis; (5) interpretation; (6) background information; (7) informed 
judgement as a culminating reflective activity in which students come to certain conclusions about the artwork. Marsh says that the modified version of the Student Centered Art Appreciation Model (SCAA) is "the best available and enjoyable and successful strategy for developing art appreciation « (Marsh, 1992, p. 13). The SCAA model has six question steps: (1) What is your first impression of the work? (2) What can you see (Description, Analysis)? (3) What does it mean (Analysis, Interpretation)? (4) What do other people think of the work (Evaluation)? (5) Do you like the work (Appreciation, Judgement)? (6) What is your impression of the work now? Has it changed? How (Conclusion, Final Personal Response)?

Encouraging the development of artistic appreciation must begin sufficiently early, believes Payne, saying: »It is necessary to keep in mind with younger learners a creative approach to art appreciation is needed « (Payne, 1990, p. 105). Research (Duh, 2016) has shown that children respond to artworks on several levels, depending on the procedure of presentation. The paintings shown in the procedure for developing appreciation through gradual uncovering evoked the most diverse associations from the children, associations that they verbalised in their own practical way. "In their imagination, they played with combinations of parts of paintings, created new links between them, and changed them as they pleased « (Duh, 2016, p. 91). Systematic teaching of art appreciation should take place on the whole vertical of institutional schooling. With little children, the level of appreciation is low; we should, however, be aware that these children are still too young and that they are unable to use the appropriate terminology. At the elementary level, E. Coates (1993) identified appreciation in 4-year-old children with the children describing objects. A guided conversation additionally activated the children's thinking, which will certainly help them in other areas of learning and in solving problems. In this way, when dealing with an artwork, students reach into their own range of mental capacity. According to Uhlig, »in intuitive thinking, which results as the continuation of thinking bound to direct observation, children aged six to eleven find it easier to perform abstract mental operations without direct observation « (Uhlig, 2005, p. 63). Today, we know that among older students, art is processed differently than other classes of objects. »Examples include style based representation semantic indeterminacy, and features that disrupt perceptual processing routines that are active in everyday perception« (Belke et al., 2010).

In conveying an artwork, "there is the fundamental question of interaction of independent perception on the one hand and the provided explanation on the other " (Barth, 200o, p. 7). When observing a painting, what we see is often conditioned by what we know (Duh et al., 2014). A directed discussion with 
students can substantially contribute to a more open approach to the artwork. "As the dialogue proceeds, comments become more and more individualised, reflecting each viewer's environment, cultural background, personal experiences, and lifestyle« (Hino et al., 2008, p. 6). A group of authors says: »Consequently in museums accompanying information should consider the possibility that understanding could be increased by carefully selected, understandable information which goes beyond mere descriptions « (Leder et al., 2006, p. 192). Concerning the nature of aesthetic experience, we believe that a combination of dependent variables covers the main dimensions of the aesthetic process. How information affects appreciation of works of art through finding meaning depends on a complex interplay of perceptual and higher order processes. This evaluates the appropriateness of information for the processing of a specific work of art for a specific perceiver (Leder et al., 2004). Higher order cognitive processes, such as finding meaning and understanding, play important roles in the appreciation of art (Leder et al., 2006).

From the viewpoint of pedagogical work in schools, we need to avoid intellectual evaluation and focus on the perception and reception of the artwork as important components of appreciation. Observation of a work of art should be an experience that »draws us to look closer, takes us into the past or future or takes us into a different world, emotionally attacks us triggering emotions that are as different and diverse as the observer himself « (Bertscheit, 2001, p. 10). A premature explanation of the artwork would be wrong, as it wastes the research capacity provided by the work of art. Research is reduced to the activity of the knowledge provided about the work of art and is at most limited to seeking conformity between the heard and the seen. In this case, the instruction and the processing of knowledge determine the action. Instead of generating a situation that would help students discover and observe, and that would establish a certain relationship to the work of art, appreciation is guided by what has been said. We are thus dealing with the speech fixation of our approach to the painting, or the victory of speech over sight (Didi-Huberman, 1990). "As part of the visual arts education of students, besides the visual expression of children, more and more attention is dedicated to the meeting of children with works of visual arts« (Kuščević et al., 2014, p. 297).

\section{Definition of the research problem}

In the present study, we monitored the development of art appreciation abilities in 9- and 10-year-old students at Slovenian primary schools. We assumed that appreciation is accessible to everyone, although not to the same 
extent, and that it is an ability that must and can be developed at school and systematically brought closer to learners. It is important that the development of artistic appreciation be more than just viewing and reacting quickly; it must be a meaningful experience. Viewing must lead to interaction between the student and the artwork, where sensory stimuli establish a direct link with memory, experience, emotions and associations. Associations allow the integration of various ideas based on common features and similarities, such as external form, colour, line and composition. They are subjective and often biographically received, and because of their proper perspective, they differ for each learner (Duh, 2004). Teachers who teach arts education must be aware that different students react to one and the same artwork in different ways, and it is important that each should react to the same work in more than one way.

\section{Purpose}

The purpose of the empirical study was to monitor the development of appreciative abilities of students in the second educational cycle of primary school. We studied the following:

the level of development of art appreciation abilities (perception, reception and knowledge) in students;

differences in the level of development of art appreciation abilities (perception, reception and knowledge) with regard to age ( 9 and 10 years), the student's gender and school stratum (urban, suburban).

\section{Hypotheses}

- H1: It is assumed that older students (10 years) have a higher level of appreciation.

- H1.1: It is assumed that older students (10 years) have a higher level of perception.

- H1.2: It is assumed that older students (10 years) have a higher level of reception.

- $\quad H 2$ : It is assumed that girls have a higher level of appreciation.

- H2.1: It is assumed that girls have a higher level of perception.

- H2.2: It is assumed that girls have a higher level of reception.

- H3: It is assumed that there are no statistically significant differences in the level of appreciation between students in the urban and suburban strata.

- H3.1: It is assumed that there are no statistically significant differences in the level of perception between students in the urban and suburban strata. 
- H3.2: It is assumed that there are no statistically significant differences in the level of reception between students in the urban and suburban strata.

\section{Method}

The empirical study is based on the descriptive and causal non-experimental method of empirical research.

\section{Research sample}

The study was conducted among a non-probability convenience sample of 9-year-old $(\mathrm{n}=1492)$ and 10-year-old $(n=1365)$ students in Slovenian primary schools. Together, the sample comprised 2,794 students $(n=2794)$. The sample differs with regard to school stratum, with 1579 students (56.51\%) attending urban schools and 1215 students (43.49\%) attending suburban schools. There were 1449 (51.86\%) boys and 1345 (48.12\%) girls. At the level of inference statistics (statistics of testing hypotheses), the sample represents a simple random sample from a hypothetical population.

\section{Data collection procedures and instrument}

The data were collected by students of primary education from the Faculty of Education, University of Maribor, within the framework of their mandatory practice teaching in primary schools in April 2015 and 2016. The AP test, which previous studies (Berce-Golob, 1990; Duh, 2004; Duh et al., 2012; Duh \& Herzog, 2015; Duh \& Kljajič, 2013; Duh \& Korošec, 2014; Duh et al., 2014; Kraguljac \& Karlavaris, 1970; Matrić \& Duh, 2015;) have shown to be a test with appropriate measurement characteristics (validity, reliability, objectivity and sensitivity), was used. The reliability of this test is confirmed by its use in the present study as the Cronbach alpha coefficient of reliability $(\alpha=.745)$.

The test comprises eight questions: seven closed type (multiple answers) and one open type question. The questionnaire adheres to the following principles: (1) the questions must be designed on the basis of concrete reproduction, (2) the questions must require a descriptive answer, not an evaluative answer, (3) each question must shed light on the observed part that the tester is interested in, and (4) the number of elements to which the question relates must be limited. All of the questions relate to Paul Cezanne's The Blue Vase (oil on canvas $52 \times 63 \mathrm{~cm}$, Musée d'Orsay, Paris). The first set of questions (1-4) resulted in data on the perceptive abilities of the students. The first question in this set establishes whether 
the students perceive the essence of the artistic message or the dominant part of the motif. Viewing the reproduction, they are asked for the most important object in the painting. They can indicate the wall with the window, the vase and flowers, or the table and its objects. The next question is aimed at establishing the students' sensitivity to the quantity of the colours in the painting. They can choose between three pairs of colours that they see as predominant (red and blue, green and blue, ochre and blue). In the next question, the students establish the intensity of the colours in the painting. They must indicate the part of the painting in which the colours are the strongest. The following answers are provided: in the bouquet, on the desk, in the background. The answers to the last question reflect the students' sensitivity to the painting's design. Their answers allow us to determine the extent to which the students are familiar with artistic language. The students note down whether they would add anything to the painting (on the plate, the table or in the bouquet). The second set of questions (5-7) resulted in data on the students' receptive abilities. In the first question, they have to find and indicate the part of the painting or the motif that drew their attention. They need to express in one sentence what drew their attention and why. The next question relates to the understanding of the painting as an enduring work of art. Based on their observation of the painting, the students had to answer the following questions: Do the beauty and the freshness of the depicted flowers give an impression of current growth and freshness, or an impression of eternal duration? The next question in this set is aimed at establishing the students' overall impression of the artwork. While observing the reproduction, the students note how they would feel in a room that held the vase and flowers from the painting. They are able to choose from three pairs of moods: sad and unhappy, calm and pensive, cheerful and vivacious. The last question (8) resulted in data on the students' knowledge of the basics of visual arts theory. This question is used to verify the students' understanding of the basics of visual arts theory, as they need to identify the basic means of expression in painting. The following answers are provided: colour and surface, line and form, space and mass.

\section{Data processing procedures}

The collected data were processed at the level of descriptive and inference statistics. The following methods were used:

- frequency distribution ( $\mathrm{f}, \mathrm{f} \%$ ) of the characteristics of the participants;

- descriptive statistics of the scores in individual questions, sets of questions and the whole test (Minimum - MIN, Maximum, MAX, Mean $x$, Standard Deviation - SD, Skewness - Skew, Kurtosis - Kurt); 
- $\quad$ t-test for independent samples to verify differences with regard to the students' age, gender and stratum in their achievements in sets of questions and the whole test (perception, reception, appreciation);

- $\quad$ Cohen's $d$ value as the measure of effect size;

- regression analysis of the influence of predictors (gender, grade, stratum).

\section{Results}

\section{Analysis of the students' results in the AP test: The sample of students as a whole}

We analysed the results in individual tasks and in sets of tasks related to perception, reception and knowledge, as well as the result in the AP test as a whole.

Table 1

Descriptive statistics of students' results in the AP test

\begin{tabular}{lccccccc}
\hline & & \multicolumn{2}{c}{ Range } & Mean & $\begin{array}{l}\text { Standard } \\
\text { deviation }\end{array}$ & Skewness & Kurtosis \\
\cline { 3 - 8 } Tasks & $\mathbf{n}$ & MIN & MAX & $\overline{\boldsymbol{X}}$ & SD & Skew & Kurt \\
\hline Perception 1 & 2794 & 0 & 4 & 2.623 & .827 & -1.834 & 1.712 \\
Perception 2 & 2794 & 0 & 3 & 1.467 & .767 & -1.003 & -.549 \\
Perception 3 & 2794 & 0 & 4 & 3.150 & 1.508 & -1.273 & -.240 \\
Perception 4 & 2794 & 0 & 4 & 3.148 & 1.120 & -.983 & -.104 \\
Reception 5 & 2794 & 0 & 4 & 2.121 & 1.050 & -.514 & -.497 \\
Reception 6 & 2794 & 0 & 3 & .985 & 1.408 & .731 & -1.465 \\
Reception 7 & 2794 & 0 & 4 & 2.010 & 1.116 & -.372 & -1.550 \\
Knowledge 8 & 2794 & 0 & 3 & 1.846 & 1.459 & -.473 & -1.774 \\
\hline Total & & & & & & & \\
Perception & 2794 & 1 & 13 & 10.388 & 2.300 & -.753 & .027 \\
Reception & 2794 & 0 & 10 & 5.117 & 2.225 & .082 & -.558 \\
Appreciation & 2794 & 2 & 26 & 17.351 & 3.742 & -.368 & -.067 \\
\hline
\end{tabular}

The distribution of the results achieved in all of the perception tasks (4) is left asymmetric, and thus dominated by high values. This is particularly true for task one $(K A=-1.834)$, where the data shows extreme pointedness $(K S=1.712)$, 
which means that there are few differences between the results. The other tasks show the kurtosis of the results, which means that there is a larger distribution of average results, or that there is a medium-large difference between them. Perceiving artworks is a continuous practice, and the students recognise the basic artistic structures of artworks, so this part did not represent a particular problem for students. Question four (Perception 4) required a more comprehensive response concerning the students, but they answered this question well, too.

In the reception tasks (3), the distribution of scores is rather symmetric and slightly more flattened. This indicates that the students were somewhat less successful in the reception tasks than in the perception tasks. In this case, it is about receiving a work of art as an integral masterpiece. The questions examined the students' artistic experience of the painting, which concerns their emotions. The analysis of the overall results confirms the left asymmetry in perception; thus, the prevailing above-average solving of tasks involving perception and symmetry, and the prevailing average success level of students in the reception tasks, resulting in a prevailing average level of appreciation among 9- and 10-year-old students.

\section{Analysis of the students' results in the AP test according to their age and gender, and the stratum of school}

First we present the students' results in individual tasks, then combined according to the set (perception, reception), and finally their results in the AP test as a whole, according to age, gender and stratum.

\section{a. The role of age}

In the case of perception, the assumption of homogeneity on which the t-test is based is not justified, so we quote the outcome of the approximation method, while in the other two cases the condition for the usual t-test is fulfilled. The outcomes indicate that in perception, the difference between 9- and 10-yearold students is statistically significant $(P=.008)$, with 10-year-old students performing better. Likewise, there is a statistically significant difference $(P=.000)$ between 9- and 10-year-old students in reception. Based on this, we can confirm research hypotheses H1.1 and H1.2. With the level of art appreciation ability, the results also indicate a statistically significant difference $(P=.000)$ in favour of the older students. With this result, hypothesis $\mathrm{H}_{1}$ is also confirmed. Art appreciation is an ability that can be developed with quality educational work in the same way as other abilities. The older students' richer experience of art, as well as their associations with and knowledge of art, corroborate this. 
Table 2

Results of the t-test in the total results for perception, reception and appreciation with regard to the students' age

\begin{tabular}{|c|c|c|c|c|c|c|c|c|c|}
\hline \multirow[t]{2}{*}{ Ability } & \multirow[t]{2}{*}{ Age } & \multirow[t]{2}{*}{$\mathrm{n}$} & \multirow{2}{*}{$\begin{array}{l}\text { Mean } \\
\bar{x}\end{array}$} & \multirow{2}{*}{$\begin{array}{c}\begin{array}{c}\text { Standard } \\
\text { deviation }\end{array} \\
\text { SD }\end{array}$} & \multicolumn{2}{|c|}{$\begin{array}{c}\text { Test of } \\
\text { homogeneity } \\
\text { of variances }\end{array}$} & \multicolumn{2}{|c|}{$\begin{array}{c}\text { Test of } \\
\text { differences } \\
\text { between means }\end{array}$} & \multirow{2}{*}{$\begin{array}{c}\text { Cohen's } \\
\text { d }\end{array}$} \\
\hline & & & & & $F$ & $P$ & $\mathrm{t}$ & $P$ & \\
\hline \multirow{2}{*}{ Perception } & 9 & 1429 & 10.276 & 2.352 & \multirow{2}{*}{4.012} & \multirow{2}{*}{.045} & -2.636 & .008 & \multirow{2}{*}{.10} \\
\hline & 10 & 1365 & 10.505 & 2.240 & & & (approx & hation) & \\
\hline \multirow{2}{*}{ Reception } & 9 & 1429 & 4.962 & 2.213 & \multirow[b]{2}{*}{.477} & \multirow[b]{2}{*}{.490} & \multirow{2}{*}{-3.790} & \multirow[b]{2}{*}{.000} & \multirow[b]{2}{*}{.14} \\
\hline & 10 & 1365 & 5.280 & 2.226 & & & & & \\
\hline \multirow{2}{*}{ Appreciation } & 9 & 1429 & 16.980 & 3.755 & \multirow{2}{*}{.035} & \multirow{2}{*}{.853} & \multirow{2}{*}{-5.389} & \multirow{2}{*}{.000} & \multirow{2}{*}{.20} \\
\hline & 10 & 1365 & 17.740 & 3.690 & & & & & \\
\hline
\end{tabular}

It is worthwhile noting, however, that for the different abilities (perception, reception, appreciation), the size of the effect of age is small $(d<.50)$; therefore, the determined advantage of 10-year-old students over 9-year-old students is small, and thus presumably also practically irrelevant. The level of development of art appreciation could increase if the teacher placed more emphasis on in-depth, empathic observation of artworks in the introductory part of art classes. Along with motivation, the latter is intended for the recognition of the individual elements of an art task and their visualisation, which can lead to higher quality and more creative artistic solutions. The quality performance of art evaluation in the concluding section of art education classes can also contribute to the development of art appreciation.

\section{Figure 1}

Distribution of arithmetic means $(\bar{x})$ of scores with individual tasks according to the age of the students

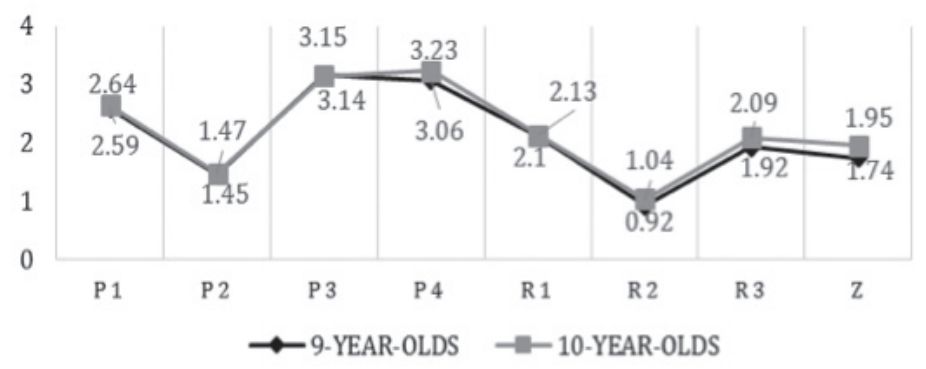


From the graph in Figure 1, it is evident that the older students were more successful in solving the tasks than the younger ones. Their advantage is somewhat more noticeable with the reception tasks than with the perception or knowledge tasks. Better perception and identification of what is essential in a work of art involves experience and learning, which is why the older students performed slightly better in these tasks. Similarly, in the last task, the older students also demonstrated better knowledge. The test of statistically significant differences is based on the overall results for the sets of tasks.

\section{b. The role of gender}

Table 3 presents the results of the statistical tests of the gender differences in the overall results for the sets of tasks.

Table 3

Results of the t-test in the total results for perception, reception and appreciation with regard to the students' gender

\begin{tabular}{|c|c|c|c|c|c|c|c|c|c|}
\hline \multirow[t]{2}{*}{ Ability } & \multirow[t]{2}{*}{ Gender } & \multirow[t]{2}{*}{$\mathrm{n}$} & \multirow{2}{*}{$\begin{array}{l}\text { Mean } \\
\bar{x}\end{array}$} & \multirow{2}{*}{$\begin{array}{c}\begin{array}{c}\text { Stand. } \\
\text { devia- } \\
\text { tion }\end{array} \\
\text { SD }\end{array}$} & \multicolumn{2}{|c|}{$\begin{array}{c}\text { Test of } \\
\text { homogeneity of } \\
\text { variances }\end{array}$} & \multicolumn{2}{|c|}{$\begin{array}{c}\text { Test of } \\
\text { differences } \\
\text { between means }\end{array}$} & \multirow{2}{*}{$\begin{array}{c}\text { Cohen's } \\
d\end{array}$} \\
\hline & & & & & $F$ & $\mathrm{P}$ & $\mathrm{t}$ & $\mathrm{P}$ & \\
\hline \multirow{2}{*}{ Perception } & M & 1449 & 10.086 & 2.3802 & \multirow{2}{*}{15.363} & \multirow{2}{*}{.000} & -7.295 & .000 & \multirow{2}{*}{.28} \\
\hline & $\mathrm{F}$ & 1345 & 10.713 & 2.166 & & & (approx & nation) & \\
\hline \multirow{2}{*}{ Reception } & M & 1449 & 4.929 & 2.220 & \multirow{2}{*}{.289} & \multirow{2}{*}{.591} & \multirow{2}{*}{-4.657} & \multirow{2}{*}{.000} & \multirow{2}{*}{.18} \\
\hline & $\mathrm{F}$ & 1345 & 5.320 & 2.213 & & & & & \\
\hline \multirow{2}{*}{ Appreciation } & M & 1449 & 16.810 & 3.803 & \multirow{2}{*}{9.394} & \multirow{2}{*}{.002} & -8.014 & .000 & \multirow{2}{*}{.30} \\
\hline & $\mathrm{F}$ & 1345 & 17.933 & 3.587 & & & \multicolumn{2}{|c|}{ (approximation) } & \\
\hline
\end{tabular}

In the case of reception, the assumption of the homogeneity of variance is justified, so here we refer to the usual t-test and to its approximation in the analysis of perception $(P=.000)$ and appreciation $(P=.000)$, since the assumption of homogeneity is not justified.

There is a statistically significant difference between boys and girls in all three abilities: in reception $(P=.000)$, perception $(P=.000)$ and in overall appreciation $(P=.000)$, with girls having the advantage. This result confirms hypotheses $\mathrm{H}_{2}, \mathrm{H}_{2} .1$, and $\mathrm{H}_{2}$.2. In the period of late childhood, affectivity and emotionality, as essential elements of reception and appreciation, are obviously slightly more strongly expressed in girls than in boys. The differences in perception can, however, be explained by greater attention, which, at least in the 
school environment, is more characteristic of girls. Values $d(d<.50)$ confirm that the effect of gender is small in all three dimensions. Like age, gender is not a factor that plays an important role in practice from the viewpoint of the development of art appreciation abilities. We can therefore conclude that from the viewpoint of reception and appreciation, there are indeed differences between the genders at a statistically significant level; from the viewpoint of developing art appreciation as an ability that should provide girls with better functioning levels than boys, these differences are not significant.

\section{Figure 2}

Distribution of arithmetic means $(\bar{x})$ of scores with individual tasks according to gender

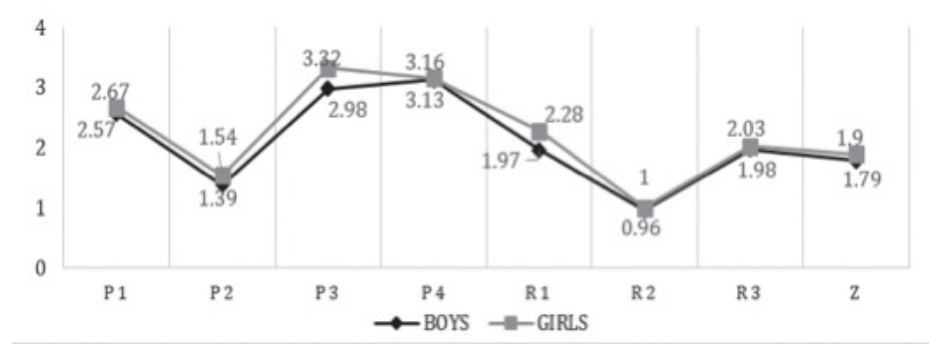

As shown in the graph in Figure 2, the girls solved all of the AP test tasks better than the boys. The advantage of girls at the level of the development of art appreciation abilities is expected, since in the period of adolescence girls are emotionally more receptive, which predominantly shows in reception, hence in the reception of works of art.

\section{c. The role of stratum}

The results of the statistical test of the differences in the overall results for the sets of tasks according to stratum are presented in the following table. 
Table 4

Results of the t-test in the total results for perception, reception and appreciation with regard to stratum

\begin{tabular}{|c|c|c|c|c|c|c|c|c|c|}
\hline \multirow[t]{2}{*}{ Ability } & \multirow[t]{2}{*}{ Stratum } & \multirow[t]{2}{*}{$\mathrm{n}$} & \multirow{2}{*}{$\begin{array}{l}\text { Mean } \\
\bar{x}\end{array}$} & \multirow{2}{*}{$\begin{array}{c}\begin{array}{c}\text { Stand. } \\
\text { deviation }\end{array} \\
\text { SD }\end{array}$} & \multicolumn{2}{|c|}{$\begin{array}{c}\text { Test of } \\
\text { homogeneity } \\
\text { of variances }\end{array}$} & \multicolumn{2}{|c|}{$\begin{array}{c}\text { Test of } \\
\text { differences } \\
\text { between } \\
\text { means }\end{array}$} & \multirow{2}{*}{$\begin{array}{c}\text { Cohen's } \\
\text { d }\end{array}$} \\
\hline & & & & & $F$ & $P$ & $\mathrm{t}$ & $P$ & \\
\hline \multirow{2}{*}{ Perception } & urban & 1579 & 10.484 & 2.305 & \multirow{2}{*}{.113} & \multirow{2}{*}{.736} & \multirow{2}{*}{2.523} & \multirow{2}{*}{.012} & \multirow{2}{*}{.10} \\
\hline & suburban & 1215 & 10.263 & 2.289 & & & & & \\
\hline \multirow{2}{*}{ Reception } & urban & 1579 & 5.184 & 2.267 & \multirow{2}{*}{4.300} & \multirow{2}{*}{.038} & \multirow{2}{*}{1.816} & \multirow{2}{*}{.069} & \multirow{2}{*}{.07} \\
\hline & suburban & 1215 & 5.031 & 2.167 & & & & & \\
\hline \multirow{2}{*}{ Appreciation } & urban & 1579 & 17.461 & 3.738 & \multirow{2}{*}{.039} & \multirow{2}{*}{.844} & \multirow{2}{*}{1.777} & \multirow{2}{*}{.076} & \multirow{2}{*}{.07} \\
\hline & suburban & 1215 & 17.207 & 3.744 & & & & & \\
\hline
\end{tabular}

The assumption of the homogeneity of variance is justified in all three analyses. The outcomes of the t-test indicate that in perception $(P=.012)$, there are statistically significant differences between students from the urban and suburban strata. This result indicates that hypothesis $\mathrm{H}_{3} .1$ must be rejected. For the other two abilities, a tendency towards difference is expressed. Given this result, hypotheses $\mathrm{H}_{3}$ and $\mathrm{H}_{3}$.2, referring to the role of stratum, can be confirmed (reception: $P=.069$; appreciation: $P=.076$ ). The higher average scores of students in urban schools indicate that the urban or suburban school environment affects students' art appreciation abilities. These results are certainly surprising, since all schools, both urban and suburban, are equipped with modern ICT that allows direct observation of quality reproductions of artworks during the educational process. This should also be a constant in modern teaching of art. From the results, we can conclude that students in urban schools are more frequently in contact with visual artworks; it is also likely that they have better access to museums and art galleries. The values of $d(d<.10)$ are, however, low, which suggests that the effect of stratum is so small that it is practically irrelevant. Art appreciation is an ability that teachers should develop in students with quality educational work, irrespective of the stratum of the school. 


\section{Figure 3}

Distribution of arithmetic means $(\bar{x})$ on scores in individual tasks according to stratum

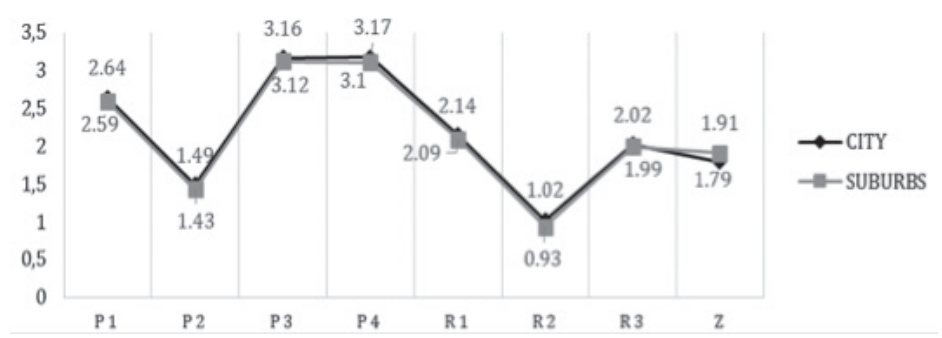

The results indicate that in solving all of the tasks, students in urban schools performed better than students in suburban schools, except in knowledge, where students in suburban schools performed better.

\section{Conclusion}

Within the framework of empirical research performed on a large $(n=$ 2794) non-random sample of 9- and 10-year-old students at Slovenian urban and suburban schools, we examined the level of students' appreciation abilities, while also statistically controlling the role of age and gender, and of school stratum. We found that the students' perceptive abilities are more highly developed than their receptive abilities, while the overall level of appreciation abilities is rather average. The perception of a work of art is the condition for developing art appreciation and is, to a large or small degree, innate to all students. Art activities in school should evoke emotional responses in students. Subtlety of perception, which may lead to the quality reception of an artwork, whereby emotional and spontaneous components are gradually joined by conscious and rational components, is a matter of learning and exercise (Duh, 2004). The existence of statistically significant differences (either in perception or reception only, or in appreciation) was detected in the factors of age and gender. Regarding the total sample, we can see that appreciation abilities are more highly developed in older students and in girls. The differences in the level of art appreciation abilities detected between 9- and 10-year-old students are small $(d<.50)$ and thus statistically practically insignificant. This finding has been confirmed in other research (Duh \& Kljajić, 2013), with progress in the area of art appreciation having been determined among 6-, 7-, and 8-year-old students. A study (Duh et al., 2014) in which a higher level of art appreciation development was 
identified among 14-year-old students than 11-year-old students presents similar findings. In the latter study, girls also performed better than boys. In another study with interesting results (Jackson, 2009), the author does not find progress in the development of art appreciation during the transition from primary to secondary school at a level of statistical significance, instead finding regression.

In our research, we have also reached conclusions about all three factors: age, gender and especially for stratum. It is true, however, that their effect is small; based on our findings, we do not, therefore, ascribe them a practically relevant role in the existing process of the development of students' appreciation abilities in the second educational cycle of primary school. We have known for a long time (Kraguljac \& Karlavaris, 1970) that we can achieve a positive effect on students' artistic creativity by developing art appreciation abilities. This means that teachers in schools should devote the same level of attention to the development of art appreciation as they do to the artistic creative work of the students. School programmes should develop art appreciation in all students on the basis of artistic content. The task of teachers is to find possibilities and realise them in accordance with the modern paradigm of visual arts education, which stresses the equal importance and positive mutual interaction of artistic creation and art appreciation. Art appreciation is certainly an ability that can be developed through quality educational work.

\section{References}

Arts education. (1996). A bibliography for the secondary level. Instructional Resources Unit. Curriculum and Instruction Branch.

http://www.sasked.gov.sk.ca/docs/arts-ed/visart102030/vavwaw.htm

Barth, W. (2000). Kunstbetrachtung als Wahrnehmungsübung und Kontextunterricht. Grundlagen und Unterrichtsbeispiele [Viewing art as a perception exercise and context teaching. Basics and teaching examples]. Schneider Verlag Hohengehren.

Belke, B., Helmut Leder, H., Strobach T., \& Carbon, C. C. (2010). Cognitive fluency: High-level processing dynamics in art appreciation. Psychology of Aesthetics, Creativity, and the Arts, 4(4), 214-222.

Berce-Golob, H. (1990). Metode likovno vzgojnega dela v osnovni šoli na področju slikarstva [Methods of art education in primary school in the field of painting] (Unpublished doctoral dissertation).

Akademija za likovno umetnost.

Bertscheit, R. (2001). Bilder werden Erlebisse. Mitreissenden methoden zur aktiven Bildbetrachtung in Schule und Museum [Pictures become experiences. Exciting methods for active image viewing in schools and museums]. Verlag an der Ruhr.

Coates, E. (1993). The language of appreciation through talking and making. Educational Review, 
45(3), 251-262. http://www.informaworld.com/smpp/title content=t71341568o

Didi-Huberman, G. (1990). Was Wir sehen blickt uns an. Zur Metapsychologie des Bildes [What we see looks at us. On the metapsychology of the image]. Hanser Verlag.

Duh, M. (2004). Vrednotenje kot didaktični problem pri likovni vzgoji [Evaluation as a didactic problem in art education]. Pedagoška fakulteta UM.

Duh, M. (2016). Art appreciation for developing communication skills among preschool children.

CEPS Journal, 6(1), 71-94.

Duh, M., Čagran, B., \& Huzjak, M. (2012). Quality and quantity of teaching art appreciation.

Croatian Journal of Education, 14(3), 625-655.

Duh, M., \& Herzog, J. (2015). Monitoring the level of art appreciation of fourth-grade primary school students, Croatian Journal of Education, 18(sp.ed.2), 35-50.

Duh, M., \& Kljajič, A. (2013). The level of art appreciation abilities of students in lower primary school grades. Školski vjesnik 62(2/3), 191-207.

Duh, M., \& Korošec Bowen, A. (2014). The development of art appreciation abilities of pupils in primary school. The New Educational Review, 35(2), 42-54.

Duh, M., \& Zupančič, T. (2013). Likovna apreciacija in metoda estetskega transferja [Art appreciation and the method of aesthetic transfer]. Journal of Elementary Education, 6(4), 71-86.

Duh, M., Zupančič, T., \& Čagran B. (2014). Development of art appreciation in 11-14 year-old students. The International Journal of Art \& Design Education, 33(2), 208-222.

Funch, B. S., Krøyer, L. L., Roald T., \& Wildt E. (2012). Long-term effect of aesthetic education on visual awareness. The Journal of Aesthetic Education, 46(4) 96-108.

https://www.jstor.org/stable/10.5406/jaesteduc.46.4.009

Healey, D., \& Runco, A. M. (2006). Could creativity be associated with insomnia? Creativity Research Journal, 18(1), 39-43. http://web.a.ebscohost.com/ehost/pdfview-er/pdfviewer?vid=3\&sid=d8f82oa49obd-4855-8e68-3f 34102096 c9\%40sessionmgr4010

Hino, Y., Iwasaki, Y., Ueno, K., Okazaki, A., \& Okumura, T. (2008). Another trend in art appreciation through dialogues. The $32^{\text {nd }}$ InSEA World Congress and Research Conference. Proceeding CD. Osaka, Japan.

Ishizaki, K., Wang, K., \& Parsons, M., (2008). Learning about appreciation skills: Case study of two teenagers, Congress Proceedings of $32^{\text {nd }}$ In SEA World Congress and Research Conference (pp. 132-141). Osaka, Japan.

Jackson, E. (2009). Viewing the arts: A cross-sectional look at art appreciation across age groups. A Rising TIDE, 3(2010).

http://www.smcm.edu/educationstudies/pdf/rising-tide/volume-3/eric-jackson-mrp.pd Jucker, J. L., \& Barrett, J. L. (2011) Cognitive constraints on the visual arts: An empirical study of the role of perceived intentions in appreciation judgements. Journal of Cognition and Culture, 11(1), $115-136$.

Kraguljac, M., \& Karlavaris, B. (1970). Estetsko procenjivanje u osnovnoj školi [Aesthetic assessment in primary school]. Umetnička akademija. 
Kuščević, D., Kardum, G., \& Brajčić, M. (2014). Visual preferences of young school children for painting from the $20^{\text {th }}$ century. Creativity Research Journal, 26(3), 297-304.

Law Suk Mun, S. (2010). An interdisciplinary approach to art appreciation. New Horizons in Education, 58(2), 93-103.

Leder, H., Belke, B., Oeberst, A., \& Augustin, D. (2004). A model of aesthetic appreciation and aesthetic judgments. British Journal of Psychology, 95(4), 489-508.

Leder, H., Carbon, C. C., \& Ripsas, A. (2006). Entitling arts: Influence of title information on understanding and appreciation of paintings. Acta Psychologica, 121(2), 176-198.

Leder, H., Gerger, G., Dressler, G. S., \& Schabmann, A. (2012). How art is appreciated, Psychology of Aesthetics, Creativity, and the Arts, 6(1), 2-10.

Lomas, T. (2016). Positive ART: Artistic expression and appreciation as an exemplary vehicle for flourishing. Review of General Psychology, 20(2), 171-182. http://dx.doi.org/10.1037/gprooooo73 Marsh, M. (1992). Art appreciation in practice in Sydney, Australia. ERIC Clearinghouse. https://eric. ed.gov/?id=ED354172

Matrić, M., \& Duh, M. (2015). Creativity among gifted and non-gifted students. The New Educational Review 40(2) 247-259.

Pagany, D. (1993). Sich Bildern oeffnen. Gedanken und Anregungen zur Bildbetrachtung in der Grundschule. Teil 2 [Open to images. Thoughts and suggestions for viewing pictures in primary school. Part 2]. Grundschulmagazin, 8(1), 43-45.

Payne, M. (1990). Teaching art appreciation in the nursery school - its relevance for 3 and 4 year olds. Early Child Development and Care, 61(1), 93-106. http://dx.doi.org/10.1080/0300443900610112 Roald, T. (2008). Toward a phenomenological psychology of art appreciation. Journal of Phenomenological Psychology, 39(2), 189-212. https://doi.org/10.1163/156916208X338783

Seabolt, B. O. (2001). Defining art appreciation. Art Education, 54(4), 44-49.

Seumel, I. (2001). Assoziative Rezeptionsverfahren [Associative reception processes].

Kunst+Unterricht, 2(53), 4-10.

Tinio, P. P. L. (2013). From artistic creation to aesthetic reception: The mirror model of art. Psychology of Aesthetics, Creativity, and the Arts, 7(3), 265-275.

Uhlig, B. (2005). Kunstrezeption in der Grundschule. Zu einer grundschulspezifischen

Rezeptionsmethodik [Art reception in primary school. Towards a primary school specific reception method]. Koaped. 


\section{Biographical note}

Jerneja Herzog, $\mathrm{PhD}$, is an associate professor in the filed of didactics of fine art on the Faculty of Education at University of Maribor, Slovenia. Her research interests includes the field of artistic creativity, art appreciation, contemporary art in education, fine arts in the experience of the visually impaired, museum pedagogy, artistic intellectual abilities of children and adolescents. She is the author and co-author of numerous scientific and professional articles and monographs.

Matjaž Duh, PhD, is a full professor of art pedagogy and a researcher at the Faculty of Education, University of Maribor, Slovenia. His scientific research area includes the field of artistic creativity, artistic appreciation, artistic design and artistic intellectual abilities of children and adolescents. He is also researching the introduction of contemporary art practices in primary school art curricula. He is the author and co-author of numerous scientific and professional articles and monographs. 